\title{
Public Value and Privatization of Property Rights in the Americas
}

\author{
Juan Ilich Perez Garcia, Martín C. Vera Martinez \\ UABC (Universidad Autónoma de Baja California), Tijuana, Mexico
}

\begin{abstract}
Privatization processes in Latin America are contemporary issues, starting from the last decades of the 20th century. As a region initially settled by newcomers encouraged by its endowments of abundant labor, natural resources, and in most cases-temperate climate, European colonization created extractive institutions which have endured up to date. In comparison, North America passed through a process of late settlements but early institutionalization, detonated by a strong political culture and decentralized public power, which in turn fostered transference of property rights to its citizens, developing distributive institutions and government legitimacy, a character to measure public value when analyzing results of public policies. When engaging in public policies toward private property in Latin America, is it seen as an institution able to build added value to both government and society? This is the point the debate manages to attain.
\end{abstract}

Keywords: public value, property rights, public value, private property, extractive institutions, distributive institutions

It is said that the more democratic a country is, the more legitimation its government has, but perhaps in the case of Latin America, political experiences could not sustain that proposition. As one of the most affected regions due to the lack of governments' legitimacy in most nations, its citizens are simply not validating the actions from their public representatives, nor they trust institutions even have a long-term plan regarding public management.

Being one of the most heavily affected regions by dictatorships up to the 1980s, but perhaps in the case of Latin American political experience such as the Junta Militar in Argentina (Soledad Catoggio, 2010), Augusto Pinochet in Chile and so on, exhausting regimes saw popular preferences turn toward different type of governments, plunging authoritarian regimes with discontent: In spite of their economic efforts to sustain political power, lack of people's freedom was too high a price to pay for them.

Thus, recent decades saw democratic regimes emerge south of the border and turn toward different type of governments, and in spite of their economic efforts to sustain those regimes even in their cruelest stages in the region, elections came for both men and women considered as adults in their respective countries, starting to vote for the candidate they hoped better represented their interests (Colomer, 2004, p. 176), as well as the political party considered as the correct choice in the electoral spectrum.

Corresponding author: Juan Ilich Perez Garcia, Ph.D. candidate in Global Development Studies, Faculty of Economics, UABC (Universidad Autónoma de Baja California), Tijuana, Mexico; research fields: public policies and privatization of property rights. E-mail: ilich.perez@uabc.edu.mx.

Martín C. Vera Martinez, Ph.D., professor and researcher on public policies, Faculty of Economics, UABC (Universidad Autónoma de Baja California), Tijuana, Mexico; research fields: public administration and government transparency. E-mail: martin.vera@uabc.edu.mx. 
Still, a changing political situation meant Latinos could choose their own government whatever their electoral spectrum, enhancing their democratic rights to elect their representatives but also participate in the political decisions of their respective countries. Then, it started to arise a really integrated transnational body like the European Union, would call the acquis humaine des droits politiques ${ }^{1}$ : decision-making process of government, economic growth perspectives (Luna, Murillo, \& Schrank, 2014), social inequalities and in general, the way they could reverse what, as society, regarded the most important issues in the public agenda ${ }^{2}$. Unfortunately, many years have passed after the fall of authoritarian regimes, and most problems are still in the region, as the following Figure 1 shows.

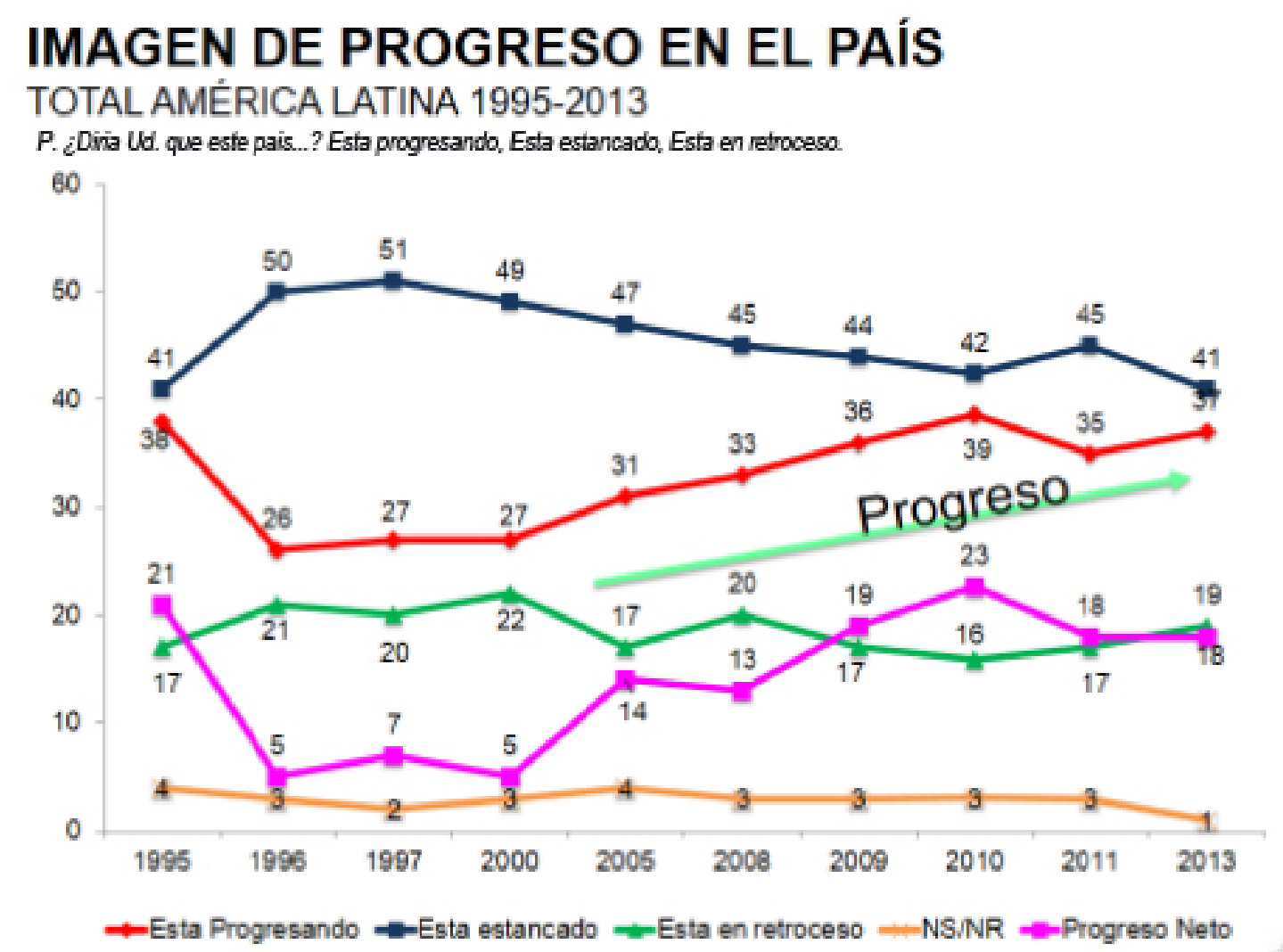

Fuente: Latinobardmetro 1995-2013

Figure 1. Progress by country in America Latina.

\footnotetext{
${ }^{1}$ In the European Union (EU), harmonization processes of local regulation, national and international Public and Private Law developed throughout the integration process of its members, following the creation of the European Coal and Steel Community in 1951, was the basis of a new legal body called European Union Law, integrated in what is denominated acquis communaitare, which in the French language refers to a composition of rules in the EU. Thus, human rights specifically evolved for public policy creation and participation can be regarded by their beholders as an acquis des droits politiques, fostering citizens' involvement in public power.

${ }^{2}$ Concluding information based on website (www.latinobarometro.org) on July 9, 2014, on the work "La imagen de los países y sus democracias", translated as "Views of the Latin American Countries and Their Democratic Regimes", where most people interviewed concludes the value of democracy depending on the assets transferred into citizens, rather than the institutional strengths derived from it.
} 


\section{PROBLEMA MÁS IMPORTANTE DEL PAÍS TOTAL AMÉRICA LATINA 2013 - TOTALES POR PAÍS 2013}

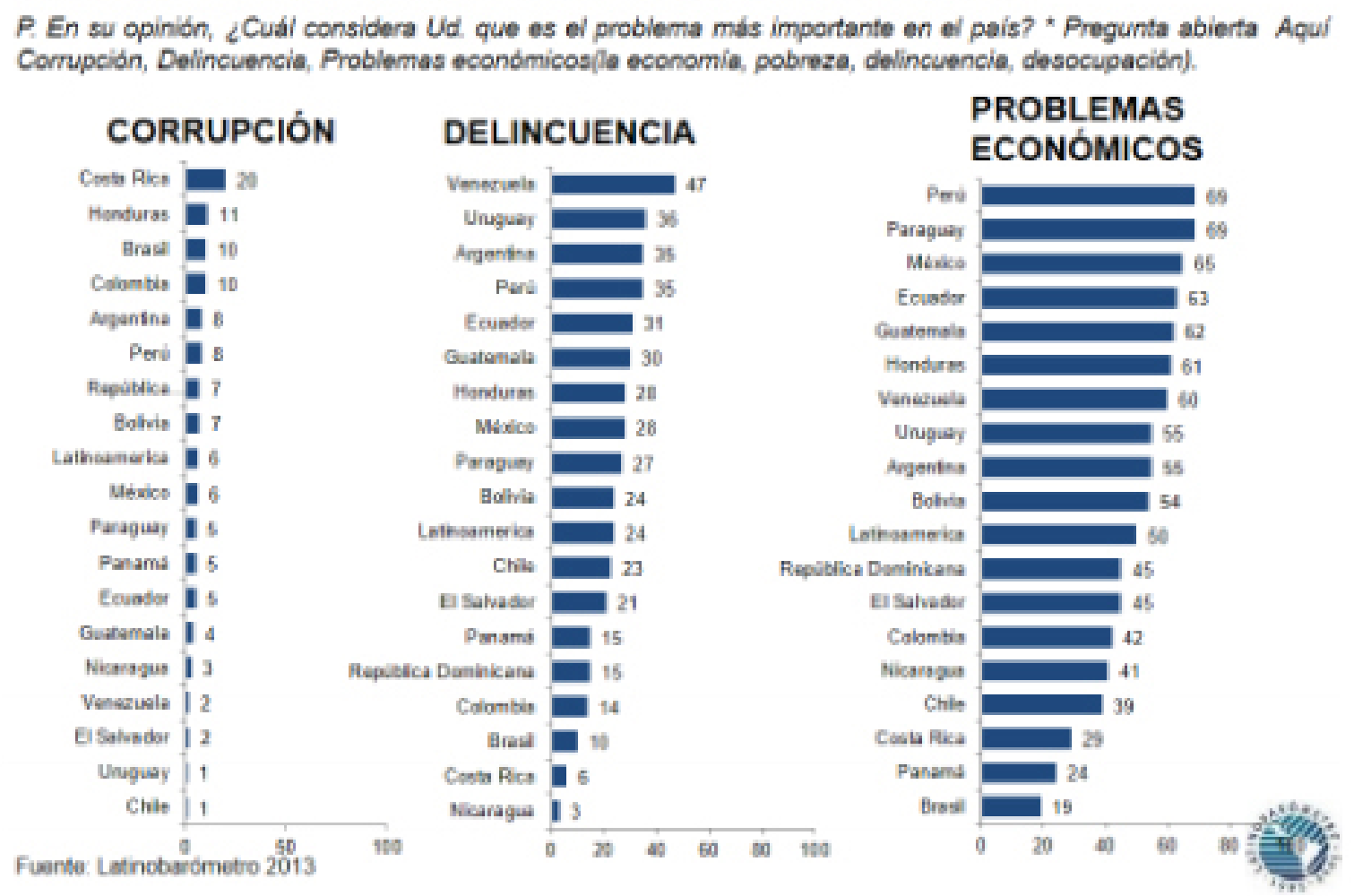

Figure 2. Most important problems by country: corruption, crime, and economic troubles.

In the case of Figure 2, what Latinobarómetro ${ }^{3}$ says about Latin America is common place: Every single citizen, whatever country analyzed, suggest is not contempt with management of their political representatives, nor the party system of their government, and would even prefer returning to be repressed up to a certain degree by a dictatorial regime, as long as basic "needs" were covered: Food, health, education, jobs, public safety, whereas democracy is not as valued as it used to decades before, as long as it does not translate in tangible benefits to society and stronger institutions.

However, public opinion is not to be debated from the grounds of a particular region, where even in the United States in 2014, Barack Obama has about the same approval level that Enrique Perique he in Mexico (Ribando Seelke, 2014, p. 1), and just about across the Atlantic Western European powers, regarded as the cradle of the values of democracy, freedom, and human rights, are not recognized for having better ratings for their representatives. Proven those statistics, could be failure of political expectations, could really be an endemic issue in the case of Latin America?

\footnotetext{
${ }^{3}$ Latinobarómetro is a private company, whose object is to poll Latin American citizen’s opinion toward economic and political issues, where in 2013 data showed a majority of citizens in the region would not mind having their liberties thwarted as long as their economic perspectives were better off than they currently are.
} 
Tabla 15: Disminución de apoyo a la democracia en 2013 respecto del promedio 1995- 2013

\begin{tabular}{|l|c|}
\hline Pais & $\begin{array}{c}\text { Diminución apoyo } \\
\text { a la democracia }\end{array}$ \\
\hline Costa Rica & 16 \\
México & 12 \\
Uruguay & 7 \\
Panamá & 6 \\
Honduras & 3 \\
Nicaragua & 3 \\
El Salvador & 1 \\
\hline \multicolumn{2}{|l|}{ Fuente: Latinobarómetro 2013 }
\end{tabular}

Figure 3. Diminishing approval to democracy in 2013, with respect to 1995-2013 average.

Taking ideas from O’Donell (1994, p. 18), it is widely recognized that progress of social participation in the Latin American public agenda was not as democratic as desired, thus further complexity has arisen when dreaming of key issues such as the regional economic perspectives, where growth stagnation has driven social inequalities to a new level: No matter countries as Chile, Peru, or Colombia have quite managed to decrease poverty levels, in the case of Venezuela or Mexico their sustained level of poverty and a lack of possibilities for citizens' escalation within social structure, has made it possible to question whether political motivation is the reason itself of the Latin American dilemma, or else there is more of an institutional problem, just as Figure 3 contemplates an overall diminishing democracy approval in the region. Are governments just focusing on public interest to themselves, rather than public value toward their citizens?

To give way for political and economic structure in any given nation, sound institutions are said to be key areas. Such is the case of Property Rights Security to be discussed as a direct variable toward individual liberty and national prosperity (Levine, 2005, p. 31), in the field of Political Economy and Public Policy because of its influence on social and economic development, and useful when comparing historical evolution in these fields in the Americas: North and South, both made up from European settlement, with a very different initial degree of endowments, as well as diversity of institutional strengths nowadays.

Martín Pérez and Martín Seco (2014), speak of public value when consolidating institutions such as property policies, where society is able to validate their representatives, as long as they benefit from strengthening them: Both Property Rights and the Rule of Law are examples of historical processes of public to private transference, given the fact that they recognize a basic universal liberty which up to date, is widely seen as a human right in access to private property as a means of exercising perhaps the most important citizens' liberty, integrating society into economic processes thanks to political participation and achieving a considerable high degree for people to escalate in the social ladder; while if the opposite holds true, inequality arises as in the Mexican case ${ }^{4}$, where difference between wealth of top and bottom $10 \%$ of population is up to 33 times and the pattern repeats throughout Latin America.

As there is deeper discussion into what public value means to contemporary politics in the following chapters, there might be a direct linkage into its effect toward public policies aimed at fostering property rights when regional governments have lacked a historical enforcement via privatization processes. As such,

${ }^{4}$ Sources: INEGI (2013) and OECD (2015). 
Bozeman (2007) stated public value is differentiated from public interest as long as it society benefit seems greater after public action, and can be recognized into the following path of public to private transferences.

Public policies mean government actions coordinated with society, whether this peculiarity of property rights privatization, it must include citizens' opinions, needs, and requirements. Thus, social participation in public decisions is aimed to actively influence partition of public resources in their benefit. Property rights are an institution comprehending both tangible and intangible assets, as they match the territorial element along the public guarantee of their adherence into private hands. So, state recognition is fundamental, whereas public interest is manifest into acquiring territory from the government as its initial proprietor, it is public power validation of such transference along its enforcement among third parties and itself, giving a value to an intangible asset over territory, where individual use and social advantages derived create public value (Bozeman, 2012).

Then, public value (Ángeles, 2011) can be seen in economic terms: Historically, public transferences to private hands of property rights not only mean a piece of land, but institutional validity through government enforcement, thanks to public services such as cadastral surveys, public records, and administrative and judiciary offices. Those intangible guarantees translate into security for citizens to generate wealth: Property rights are able to enter the market, serve as economic guarantee or productive means, and being accountable as part of private assets.

Property rights served as a means to centralize economic and political power in dominant elites throughout Latin America: This institution not only prospered into the legal and financial basis that contributed to a few citizen's wealth: Pages ahead, it is debated on how vicious cycle with which Latino society could not prosper, since there were not enough social advantages of available government offices, credit institutions, roads and schools for most of them up to date, with still a lot of public value to be generated (Talbot, 2006), while the opposite held true in the US as well as Canada, in less than two centuries from sparsely populated British colonies, to prosperous economies with considerable percentage of middle-class families living better than European counterparts.

Along private property development, not only did Hispanic settlements in the Americas engaged in constructing extractive institutions, but selective wealth distribution did create stratified interests rather than public value (Shearer \& Williams, 2011) not just in economic terms, but also on social integration, a phenomenon historically linked worldwide to foster human capital in financial and civic networks, so people can manage to escalate their social position and interact with one another, a factor that could have diminished inequality as another component indirectly linked to property rights distribution (Vosburgh, 2002), with debate open when historically analyzing property and its impact on institutional advantage for public value consolidation.

Also, there cannot be forgotten the continuous degree of public power intervention on the influence on how public value is developed (Borcherding \& Lee, 2002), toward redistributing property rights, for there is seen on how just recently, citizens' participation in Latin America empowers them up to a point where the state has to limit its influence to benefit society on their decisions on private property management, and otherwise when it is the various instances of the local, State and Federal government forced to take action on changing the institution of property in order to redistribute its benefits to society as a whole, reducing natural inequalities market create and fostering wide access to those assets.

Nowadays, as political and economic participation in democratic regimes grow, most global analysts tend to question why in both developed and developing countries, growing problems such as poverty and inequality are a major concern: For debate might start on whether private property is an institution that, if led by a 
comprehensive construction of public policies including society, tends to enhance equal access to the global economy and provoke major equality, precisely by letting people win the battle over social construction of private property thanks to their access to a formal market, legitimating government participation as long as results in public policies are measured on the scale of equal growth provided by the ruling regime involving social networks, such as the ones developed in North America: Were property rights developed as an institution? Do they foster public value when privatized? Is public value present today?

\section{Colonial Settlements in Hispanic America}

Whereas European settlements in what is now the United States and Canada did not start until the late 17th century, colonization in the rest of the continent began in the late 1400s: As quickly as Christopher Columbus discovered the Americas, Spaniards and Portuguese nationals soon after, arrived in the New World seeking for fortune. However, it might have been this eagerness for glory and wealth, on such personalities as the Extremadureans Hernán Cortés or its distant cousin Francisco Pizarro ${ }^{5}$, that they initially found a massive wealth in both labor and minerals. Such endowments might not be proven to cause the creation of extractive institutions in the political and economic structure of Latin America, but the fact is being densely populated colonies with large primary sources to be extracted, might have evolved this way, while as Acemoglu, Johnson, and Robinson (2002) analyzed, initially poor areas as nowadays North America, without many indigenous people or easily identifiable mineral sources, would be able to attract two hundred years later, lots of European settlers that constructed sound institutions, such as the creation and enforcement of private property rights, and grew quickly afterwards.

According to Easterly and Levine (2002), differences in endowments, such as minerals and abundant labor in the case of Latin America, and for North American countries, few indigenous population along vast agricultural plains, shaped initial institutions on both parts, which have had long-lasting repercussions on modern countries, being precisely the protection of private property rights (Easterly \& Levine, 2002, p. 8), one of those initial institutions which has endured up to date. So far, what is for sure is that before the 1500 s, when Europeans conquered Central and South America and created the Viceroyalties of New Spain, Peru, and Brazil, they inherited large tracks of land along considerable population source for native labor and large primary sources.

Otherwise, when analyzing the population component as an endowment, there is a fact that the patterns of European organized settlement and population growth, differed quite considerably from those in the Native American period: According to the research from Engerman and Sokoloff (2002, p. 3), prior to the discovery of the New World, the distribution of the Native American population was roughly as follows: $35 \%$ in South America; $10 \%$ in the Caribbean; 47\% in Mexico and Central America; and just $8 \%$ in what would become the United States and Canada. By adding up numbers, Mexico alone had 37\% of total indigenous population, which is almost four in every 10 persons in Pre-Columbine America and less than one in 10 in the US and Canada, almost half of the land mass.

In North America alone, what now comprises Mexican territory had almost six times the inhabitants of its neighbors North of the Rio Bravo combined in less than a tenth of its size, people which were eventually turned

\footnotetext{
${ }^{5}$ Hernán Cortés was the conqueror of the Aztec Empire in what is now Mexico, what was to be named as New Spain, and Francisco Pizarro conquered the Inca Empire, nowadays Peru and called by the Spanish Kingdom Virreinato del Perú. Both were native of the Spanish region of Extremadura, as well as many other conquistadores of the time.
} 
into labor force in favor of European colonizers, mostly from Spain and Portugal, whose governments aligned in the 15th century to divide the conquered territories across the Atlantic for themselves, the most heavily populated in the Americas at that time: Spain went to Mexico, Peru and elsewhere in South America and the Caribbean, and Portugal took what is now Brazil to be colonized (Engerman \& Sokoloff, 2002, p. 3). Only the less densely populated areas were still available when the later colonizers, such as the Dutch, British, and French, arrived a century later, being those what is currently the United States, Canada, and the Caribbean countries.

Even with colonization patterns form different European countries, extractive models in Latin America could have created a pattern to favor the wealthy and influential, for regulations in the Kingdom of Spain at least, limited the number of subjects to settle in the American Viceroyalties, where there was from the beginning of the Age of Discoveries, an establishment of grants for certain group of colonizers that, in the case of the Viceroyalty of the New Spain, never surpassed 90,000 Spanish citizens for more than three centuries of colonial dominion, taking advantage of the vast, native human source of labor, the inherited infrastructure created by the Aztec and Inca civilizations in conquered territory, and mineral wealth.

\section{Pathway to Independence}

In the first decades of the 1800s, most Latin American countries challenged European colonial establishment thanks to organized groups, dissatisfied with the main regime—or as in Spain would be called "La Metrópoli", influenced by European movements of illustration and also, by the formation of the United States of America in 1776, a small group of 13 British colonies quickly gaining momentum. Soon afterwards, former viceroyalties gained independence through revolutionary movements, as the case of the United States of Mexico in 1821, direct consequence of the 1810 initial movement.

Nonetheless, comparing the independence processes between North and Latin American countries, both conquered by European kingdoms, there were two key differences: Time lapse was different, for the first case was almost 50 years before, and political regimes were dissimilar as well, since Spanish Viceroyalties as Nueva España was always a centralized colony, with a huge territory-more than four million squared kilometers formation, whereas British domains were small portions of the US East Coast, with diverse historical and religious formation and population group, whose internal political organization was quite different from the rest, conceiving a major degree of autonomy ${ }^{7}$.

Such is the case, that up until the end of the 18th century, Europeans had adopted various colonization strategies, with different institutions derived from political formations in their settlements. In the United States, a lack of sufficient indigenous population and mineral sources, might have discouraged British settlers to model extractive colonies—as in the case of Africa during the 19th and 20th centuries, but as they later established the first democracy in the world, their political culture encouraged them on three formal aspects with regards to what Acemoglu, Johnson, and Robinson (2001, p. 1375) describe as institutional advantage over their Southern

\footnotetext{
${ }^{6}$ Soon after discovering the Americas, both Spain and Portugal had the tradition of referring to the home countries as " $L a$ Metrópoli”, whereas the new domains retain their colonial status.

7 Bourbon reforms in the Spanish kingdom, as well as overseas domain, gave way through a central-based organization, where Madrid was the capital of its huge territory and Seville was the place of the archive of the then called "Indies": Viceroyalties as well, were initially composed of New Spain and Peru, modern-day countries corresponding to almost the entire regions of Latin America and the Caribbean, with the exception of Brazil. Meanwhile, each of the British 13 colonies of the American East Coast not only were much smaller in size and population than Iberian Vicerroyalties, but, though similar in ethnic component of their citizens, had a variety of religious beliefs and legal institutions.
} 
counterparts-named New Spain, Peru and Brazil. First and foremost enforcing the Rule of Law, therefore fostering protection of Private Property and last, encouraging investment as a legitimate governance, turned out toward individuals in their confidence to public power.

Engerman and Sokoloff (2002, p. 11) speak of disparities on economic structures and institutions between Mexico and the United States, for up to the initial 1700s both displayed virtual parity in terms of per capita income. Still, inequalities were already widespread: European descendants in Nueva España had total control of public power and thus, institutions served only those in charge, while North Americahad widespread access to institutional formation, helped by citizens' participation toward public redistribution of private property and public enforcement of the Rule of Law, giving way after their independence, to infrastructure and schooling expansion nationwide.

Hard data (Insulza, 2011) might then generate further debate on whether pronounced inequalities, engaged on dissimilar development across the American landscape rather than the geography/endowment hypothesis, holding environment as directly influencing the quality of land, labor and production technologies among world regions (Machiavelli, 1519; Montesquieu, 1750), for as long as there was widespread availability of natural, mineral, and labor sources in vice royal Spain and Portugal in the New World, by the time of independence of Latin American countries, institutions were much more engaged in the North and also, wealth in the independent United States and Canada had already advantaged that of the South of the Continent, and also more even distribution among their citizens.

\section{Land as a Detonator of Social Mobility}

Is there a current debate about how institutions might foster social mobility? As far as the Rule of Law and Private Property Rights concern to the Americas ${ }^{8}$, discussion is open for the direct involvement of how both variables have a direct effect on social development, a much-analyzed topic by political economists such as Daron Acemoglu (2005) or La Porta and López de Silanes (1999). According to Hernando de Soto (2001), territory is not in fact, strictly seen as an equivalent of property rights, but rather as another element, for there cannot be private property where there is no government with power and legitimacy enough as to sustaining, validating, and enforcing the Rule of Law among its citizens and the prerogatives derived from their human rights, being private property one of them. Proposition states individuals to possess land, the same as having means to feed themselves, but the territory they live and sometimes produce, transforms into private property if, and only if, society protects and validates an individual prerogative to possess such deed (Olson, 2000), defends it against third parties and rules an economic value on it.

Not astonishingly, when formal regressions about how the Rule of Law and Property Rights are seen as direct variables affecting political and economic development, such as Property Rights Alliance ${ }^{9}$ surveys and findings, countries with highest per-capita income, are also where private rights are better enforced by their own governments. Such is the case of the United States and Canada, consistently ranking not only at the top of the global median individual and family income, but where property does have an actual meaning directly

\footnotetext{
${ }^{8}$ Where there is a mention to the term "The Americas" might be understood as the economic, political, and cultural separation of the American continent, one single territorial entity, into North America, made up of the United States and Canada, and Latin America, made up of Hispanic America and the Caribbean, a composition mostly used in Social Sciences as well in comparative studies.

${ }_{9}^{9}$ Further information can be consulted in http://www.propertyrightsalliance.org, a US-based non governmental organization with yearly statistics referring to global private property rights freedom and the Rule of Law on different countries.
} 
connected with private legitimation of the state enforcing this right. When looking southwards, private rights have consistently been disregarded by government, at least in a wide-scale for society: As stated before, in colonial Latin America, the "original sin” (De Silva, 1982, p. 9) of its underdevelopment is partly discovered in the encomienda system, a grant of land for plantations and mines given by the Spanish and Portuguese crown to a selected elite; first and foremost the descubridores ${ }^{10}$, and later the peninsulares ${ }^{11}$ following the age of discoveries and three centuries afterwards, meaning exclusive exploitation rights not only limited to these particular individuals, but also feudal prerogatives of domain over indigenous people and their mineral sources, continuing themselves as the dominating elite as armed independence movements engaged by the criollos $^{12}$ in the early 19th century, gave them way to not challenge the de facto establishment, but rather making it an ever-lasting characteristic of the institutional development South of the Rio Bravo (Chasteen, 2000).

Though Spanish and Portuguese colonial America were never characterized for their social mobility, nor their institutional construction of overseas domains, an enduring trend in New Spain, prevailed in the first decades of its existence as an independent country: Suitable land for agriculture was relatively scarce, without individual private property rights over possessions, and it was not until the end of the 19th century during Porfirio Diaz Regime, that $10.7 \%$ of national territory was massively transferred to private hands, mostly foreign land development companies and few local elite known as terratenientes ${ }^{13}$, whereas as Engerman and Sokoloff (2002, p. 21) found, as much as $90 \%$ of land North of the Border had been transferred from public domain to private property, legitimating their institutions thanks to three-way axis public policies: public transferences of land to private hands, connecting urban centers and commerce across North America with massive infrastructure development; and providing nationwide schooling. By the turn of the 20th century in more than $90 \%$ of white males were able to read and write in the US and Canada... it would take more than 100 years for Latin American countries to attain such literacy ratings.

Both authors above mentioned (Engerman \& Sokoloff, 2002, p. 30) add the lack of social mobility in Latin America, as highly restrictive and controlled by the elites, thus private property took a long way to be seen as an economic deed. In other words, while in the United States, property rights were an effective institution passed from public to private control for at least $75 \%$ of its population- $90 \%$ in the case of Canada from the late 1700s, it also gave the right of homesteaders, to take advantage of a national infrastructure and schooling plan associated to Westwards expansion, integrating private property into Economics when recognized as a valuable good. In Mexico, private property and its management was such a privilege, at the beginning of the 20th century, less than $5 \%$ of population held this right.

\section{Public Policies and Private Property}

Disregarding the region of the Americas in analysis, there is the fact Europeans profoundly shaped national approaches to property rights in the New World, which is just as important as the rest of institutions colonists built in modern North and Latin America, giving comprehension on current models of private

\footnotetext{
${ }^{10}$ Descubridores is the term referred to in history to the Spanish and Portuguese sailors that discovered the Americas in the late 15 th and early 16th centuries, most of whom gave way to Hispanic dominion in the New World.

${ }^{11}$ Peninsulares is the meaning of Spanish-born people in viceroyalties of what is now Latin America, referring origin from the Iberic Peninsula and distinguishing from American-born citizens of pure European descent.

12 Though also from Spanish origin as the above mentioned, American-born Spaniards would be referred to as Criollos, and had fewer privileges than their counterparts, originating part of the conflict for independence centuries later.

${ }_{13}$ Terratenientes were the local elite of landlords inheriting long-scale rights to territorial claims as well as considerable labour force to work in agricultural-related activities, many of whom owned more than a million hectares at the height of Diaz's regime.
} 
property across the continent. First and foremost, just as society was mature enough to legitimate its government all along building institutions such as the Rule of Law, property rights were also fostered —in the case of the United States and Canada, not only by their enforcement, but also thanks to a fundamental activity developed over 250 years, demanded by civil society but made possible through government itself at a local and national level: transference and recognition of public land to private dominion. When creating the notion of private property inside a national territory, and recognizing the ultimate value public power can have in guaranteeing third parties at a local and national level: transference to be exported worldwide. As such, security of property rights is an outcome of both policy choices and social institutions (Levine, 2005).

When Douglas North (1990, p. 98) spoke of institutions, they are conceptualized as the humanly devised constrains that structure political, economic, and social interaction, consisting of both informal constraints and formal rules. Thus, talking of institutions is directly connected with providing a structure. Property rights are seen as formal economic constraints in a broad term, structuring the economy of a state where they are recognized, specified, and enforced thanks to political institutions formed and legitimated by society, for there cannot be guaranteed public policies, where there are no institutions people recognize as valid to represent public interests. Thus, in order for a policy to get its way, there has to be a state in the first term, whose power needs validation from civil society: long-lasting institutions, such as public power protection on property rights and effective operation of the Rule of Law (Easterly \& Levine, 2002, p. 26).

It is the case that the importance of institutions to structure social policies, can be seen in the case of Property Rights and the Rule of Law, since even when both are political institutions and are constrained by a legal frame, both directly influence the degree of intervention of the state in three key topics of the public agenda: economics, politics, and society; and at the same time, public policies where institutions such as property rights intervene are made if and only if, there is a substantial degree of participation of the most important actors for a legitimate state: the government itself based on these solid institutions, and social legitimation by citizens' confidence on them (Easterly \& Levine, 2002, p. 21). Public and private powers interact whenever their forces drive social change: For both the Rule of Law and Property Rights are institutions whose strength directly influences the states, and are as well influenced by the construction of a particular nation, in which its history and legal frame is no more than a backup of the institutions shaping its past, present, and future. Said so, where does society fit, and how can its citizens seen as their individual units, benefit from both institutions? What to do to measure specific benefits?

\section{Public Value in Privatization Policies: A Global Perspective}

If political institutions are granted as the most important construction in a state, then they must be built by civil society to guarantee private liberties and enforce law and regulations for a country to function. What is more, North (1990, p. 100) manages institutions as a fundamental tool for enforcement at a local, federal, and global level of social norms, entailing fundamental rights as private property over time, and even global standards of Human Rights, the Rule of Law or regulation of the global capital markets and economics.

As there is no doubt that in every given state-whether democratic or totalitarian, civil society participates in its construction, there is a path where first cultural history, as in the case of the varying model European colonists took in the Americas, and then political and institutional structuring followed by a legal frame, foster an interrelation between government and citizens. In the case of the United States, its cultural background of 13 colonies made a decentralized origin of local power, as well as a blurred sense of a single dominion of British 
origin in the New World. Soon after, independence came along with the first global democracy, a political entity fostered by the Founding Fathers ${ }^{14}$ of the US which derived in a federal government: A local, state, and national level of authority, each legitimated by society who in turn, validated the American way to exercise public authority in the inwards and outwards (or global) institutional building, accompanying democratic authorities and territorial expansion: Respect of private liberties, creation of property rights, and the triple axis of transference of public land to private property, connected with the infrastructure plan and schooling policies. These institutions in turn, made a political and economic order from its origin up to modern America, whose government gained and sustained legitimacy with both an strong institutional structure and acute political participation of civil society at the three levels of authority, developing a legal framework where as Moore (1995, p. 2) established, the American Constitution divide rather than concentrate public authority as a result of society demands.

In an environment where modern society is not constrained to a certain political system, but rather as in the case of North America, is on its way to accomplish 300 years of continued democracy under a decentralized federation strong enough to enforce existing institutions, how can many other governments as the Latin American, enforce property rights as private and not public goods an where can an institutionalization might be reached? If it does not achieve it as a long-term goal in its enforcement, theory has it people will not trust their institutions, discouraging property rights protection and with it private investment, given economic and political reasons for not doing it, for not considering the state vehement enough to respect individual rights, to formally protect what informally has transferred and a state, strong enough to enforce institutions society has accomplished, against third parties and even when necessary, against itself (Haber, Razo, \& Maurer, 2003, p. 1).

That is what public value is about: For common citizens to get together, to form the type of government they believe represents an interest, an interest of a majority, on a broad-spectrum basis of these people belonging to a state, to cede part of their autonomy in favor of the state public power, which in turn must build institutions solid enough to, when necessary, join economics and politics by arranging a public transference of goods to private hands, enhancing the most basic individual liberties of both possessing, producing, and translating into the economy a piece of the state's territory to themselves, and also to protect this acquiessential attribute of its people in order to legitimate authority society gives through government: A public value where there is a majority feeling their now called human rights are enforced thanks to modern-day institutions such as the Rule of Law, such as property rights, and where this public value is not only an abstract concept of a demagogic government, but rather of public policies for citizens to get together, and enjoy social benefits derived from them.

\section{Final Remarks}

Debate has been tried to be established on whether privatization of property rights has been a tool for social development, comparing colonial and modern history in both North and Latin America. Curiously, in the middle of the discussion, empirical evidence states a clear notion of how institutions where shaped and organized in each part of the New World and whom they benefited. Even though to a lesser or major degree, global inequalities might be an indirect result, for there are clear winners and not of institutional development

\footnotetext{
${ }^{14}$ Founding Fathers is how are called the men who gave way to the construction of the independent 13 colonies of Britain, into the United States of America.
} 
worldwide. In the case of Latin America, land policy has always been an unfortunate prime example of the ways in which institutions may have contributed to the persistence of inequality over the long run, contrary to neighboring North where institutions and political situation overcame their initial disfavoring endowment factor, lacking mineral sources, early settlements or a large native workforce, developing two of the most economic and politically advanced societies in the modern world. On the other hand, governments from the American Viceroyalties kept implementing policies to control the availability of land for private use, and institutional development of property rights in the Iberian-controlled territory entailed only available land sources to the ruling elite, maintaining the same structure five centuries later.

Property rights are along the Rule of Law, public-power enforced institutions guaranteeing human rights and individual liberties. Not surprisingly, private property has much more to do with a personal liberty than a plot of land, for its contemporary concept is a legal expression of an economic asset via political consensus, with the law as a formal instrument permitting the establishment of the rules of the game: In Latin America, legal arrangements have given way to huge projects as the expansion of the Panama Canal, where Inter American Development Bank seeks public planning toward financial assistance for public value-driven reforms. Venezuela and Bolivia, self-called socialist governments, implemented US-style land reforms for privatizing those assets, now integrated to private capital, just as Peru and Mexico did a decade before.

Nowadays, Moore and Khagram (2004) regard public value of institutional policies measured via social impact, in order to legitimate public power as long as their decisions attach public value, and debate is open worldwide: Property rights in the Americas are hot topic in affordable housing challenges in places like California, affecting not only urbanizations but also social inequalities, and on the other Iberian-American tradition countries, Spain and Argentina battle on how social financing mix affordable housing with the rest of communities, bringing legal changes to immerse social interaction among citizens from different income levels. Thus, institutional structure might encourage social development on a local, national, and global scale; its construction seems to be determinant in the degree of political freedom, as well as the allocation of resources among population for economic development and inequality reduction.

\section{References}

Acemoglu, D. (2005). Modeling inefficient institutions. United States: Massachusetts Institute of Technology.

Acemoglu, D., Johnson, S., \& Robinson, J. A. (2001). The colonial origins of comparative development: An empirical investigation. The American Economic Review, 91(5), 1369-1401.

Acemoglu, D., Johnson, S., \& Robinson, J. A. (2002). Reversal of fortune: Geography and institutions in the making of the modern world income distribution. Quarterly Journal of Economics, 117(4), 1231-1294.

Aguilar Villanueva, L. F. (1992). The making process of public policies. México: Porrúa.

Aguilar Villanueva, L. F. (1993). Public issues and government agenda. México: Porrúa.

Ángeles, L. (2011). Institutions, property rights, and economic development in historical perspective. United Kingdom: University of Glasgow.

Bardach, E. (1998). The eight steps for creating public policies. México: Economic Research and Teaching Center.

Bartolini, S., Cotta, M., Morlino, L., Panebianco, A., \& Pasquino, G. (1995). Manual of political science. Alianza Universidad Textos, Madrid, Spain.

Behn, R. D. (1994). Policies and politics analyses. Mexico.

Berman, S. (1997). Civil society and the collapse of the Weimar Republic. World Politics, 49(3), 401-429. Cambridge, MA: Cambridge University Press.

Besley, T., \& Ghatak, M. (2010). Property rights and economic development. United Kingdom: London School of Economics.

Borcherding, T., \& Lee, D. (2002). The growth of the relative size of government. United States: Claremont Colleges. 
Bozeman, B. (2007). Public values and public interest: Counterbalancing economic individualism. Washington, D.C.: Georgetown University Press.

Bozeman, B. (2012). Public values concepts and criteria: The case for "progressive opportunity" as a criterion. University of Georgia, United States.

Carstensen, V. (1987). Patterns on the American land. Journal of Federalism, 18(4), 31-39.

Chasteen, J. C. (2000). Born in blood and fire: A concise history of Latin America. New York, NY: Norton.

Colomer, J. M. (2004). Howwe vote. Worldwide electoral systems: Past, present and future. GEDISA, Barcelona, Spain.

Crosby, A. (1986). Ecological imperialism: The biological expansion of Europe 900-1900. United States: Cambridge University Press.

Damm Arnal, A. (2012). Private property: Condition of the possibility for exercising individual freedom. Friedrich Naumann Freedom Foundation. Proyect Mexico.

De Silva, S. B. D. (1982). The political economy of underdevelopment. United Kingdom: Taylor \& Francis Group.

De Soto, H. (1989). The other path. United States: Harper \& Row Publishers.

De Soto, H. (2001). The mystery of capital. United Kingdom: Black Swan.

Della Porta, D. (2000). Social capital, beliefs in government and political corruption. In S. J. Pharr and R. D. Putnam (Eds.), Disaffected democracies: What's troubling the trilateral countries? (pp. 202-229). United States: Princeton University Press.

Di Lorenzo, F. (2013). International property rights index. United States: the Property Rights Alliance.

Easterly, W. (2001). The lost decades: Developing countries' stagnation in spite of policy reform 1980-1998. Washington, D.C.: World Bank.

Easterly, W., \& Levine, R. (2002). Tropics, germs, and crops: How endowments influence economic development. Working Paper, No. 9106. Cambridge, MA: National Bureau of Economic Research.

Engels, F. (2004). The origin of the family, private property, and the state. Australia: Resistance Books.

Engerman, S., \& Sokoloff, K. L. (1994). Factor endowments, institutions, and differential paths of growth among new world economies: A view from economic historians of the United States. National Bureau of Economic Research Working Paper, No. H0066, December 1994. United States.

Engerman, S., \& Sokoloff, K. L. (2002). Factor endowments, inequality, and paths of development among new world economies. Working Paper, No. 9259. Cambridge, MA: National Bureau of Economic Research.

Evans, P. (2001). The state as a problem and solution. Governability challenges, preliminary study and collection. Mexico: CONACYT, FLACSO and Social Research Institute in UNAM.

Haber, S., Razo, A., \& Maurer, N. (2003). The politics of property rights: Political instability, credible commitments, and economic growth in Mexico. Cambridge, MA: Cambridge University Press.

Hoskins, L., \& O’Driscoll Jr., G. P. (2003). Property rights: The key to economic development. Policy Analysis, No. 482. United States.

Insulza, J. M. (2011). Inequality, democracy and social inclusion. Inequality and social inclusion in the Americas. Washington, D.C.: Organization of American States.

International encyclopedia of social sciences. (1968). New York: Mac Millan Co.

La Porta, R., \& López de Silanes, F. (1999). The benefits of privatization: Evidence from Mexico. Quarterly Journal of Economics, November 1999, 1193-1242. Cambridge, MA: National Bureau of Economic Research.

La Porta, R., Lopez-de-Silanes, F., Shleifer, A., \& Vishny, R. W. (1999). The quality of government. Journal of Law, Economics and Organization, 15(1), 222-279.

Landes, D. (1998). The wealth and poverty of nations. New York, NY: W.W. Norton.

Latinobarómetro. (2015). Chile: Latinobarometro Corporation.

Lawson-Remer, T. (2012). Property rights, growth, and conflict. United States: The New School.

Lechner, N. (2001). Political culture and democratic governability. Challenges on governability, preliminary studies and collection. Mexico: CONACYT, FLACSO and Social Research Institute in UNAM.

Levine, R. (2005). Law, endowments and property rights. Journal of Economic Perspectives, 19(3), 61-88.

Limongi, F. (2014). The Latin American way. Latin American politics and society. University of Miami, FL.

Limongi, F., \& Przeworski, A. (1993). Political regimes and economic growth. Journal of Economic Perspectives, 7(3), 51-69.

Lindblom, C. E. (1991). The policy making process. Public administration ministry. Madrid, Spain.

Locke, A. (2006). Property rights and development briefing: Property rights and economic growth. United Kingdom: Overseas Development Institute. 
Luna, J. P., Murillo, M. V., \& Schrank, A. (2014). Latin American political economy: Making sense of a new reality. Latin American Politics and Society, University of Miami, FL.

Machan, T. R. (2002). The right to private property. United States: Hoover Institution on War, Revolution and Peace.

Machiavelli, N. (1519). Discourses on Livy. New York, NY: Oxford University Press.

Mainwaring, S., \& Shugart, M. S. (2002). Presidentialism and democracy in Latin America. Buenos Aires, Argentina: Paidós.

Martín Pérez, S., \& Martín Seco, P. (2014). From thought to action... Creating public value. Public Policy Management and Analysis, New Epoch, 11(Jan-June).

Meny, I., \& Thoenig, J.-C. (1992). The public policies. Barcelona, Spain: Editorial Ariel.

Meynhardt, T. (2009). Public value inside: What is public value creation? International Journal of Public Administration, 32(3-4), 192-219.

Montesquieu, C. L. (1750). The spirit of laws. New York, NY: Cambridge University Press.

Moore, M. (1995). Creating public value: Strategic management in government. Cambridge, MA: Harvard University Press.

Moore, M. (2005). On infrastructure and private public partnerships. Proceedings from CLAD 10th International Congress Over Public Administration and State Reform. Chile.

Moore, M. (2006). Recognizing public value: The challenge of measuring performance in government. A passion for policy. United States.

Moore, M., \& Khagram, S. (2004). On creating public value. What business might learn from government about strategic management. John F. Kennedy School of Government, Harvard University, Massachusetts.

Murillo, Luna, \& Schrank. (2014). Latin American political economy: Making sense of a new reality. Latin American Politics and Society, University of Miami, FL.

National Counsel for Evaluating Social Development Policies. (2012). México.

National Territorial Strategy. (2012). Mexico: Social development ministry and institute of economic research in UNAM. México.

North, D. C. (1990). Institutions, institutional change and economic performance. Cambridge, MA: Cambridge University Press.

O’Donell, G. (1994). Delegative democracy. Journal of Democracy, 5(1), 55-69.

Olson, M. (2000). Power and prosperity: Outgrowing communist and capitalist dictatorships. United Kingdom: Oxford University Press.

Potter, L. A., \& Schamel, W. (1977). The Homestead Act of 1862. Social Education, 6(61), 359-364.

Powell, B. (2002). Private property rights, economic freedom, and well being. United States: George Mason University.

Przeworski, A. (2008). Political rights, property rights, and economic development. New York: New York University.

Przeworski, A., Cheibub, J. A., Limongi Neto, F. P., \& Alvarez, M. M. (1996). What makes democracies endure? Journal of Democracy, 7(1), 39-55.

Putnam, R. D. (1993). Making democracy work: Civic traditions in modern Italy. United States: Princeton University Press.

Rhodes, R. (1994). The hollowing out of the state: The changing nature of the public service in Britain. The Political Quarterly, 65(2), 138-151.

Ribando Seelke, C. (2014). Mexico: Background and U.S. relations. Congressional Research Service, United States.

Rodrik, D., Subramanian, A., \& Trebbi, F. (2002). The primacy of institutions over geography and integration in economic development. Boston, MA: Harvard University.

Rose, R. (1984). Understanding big government: The programme approach. London, United Kingdom: Sage Publications.

Schroder, P. (2000). New public management: Contributions for good government. Friedrich Naumann Foundation, México, D.F. Schumpeter, J. (1949). Capitalism, socialism, and democracy (3rd ed.). New York, NY: Harper Row Publishers.

Shearer, H., \& Williams, I. (2011). Appraising public value: Past, present and futures. United Kingdom: Blackwell Publishing.

Skocpol, T. (1990). The state is back on the foreground: Analysis strategy in current research. Madrid, Spain: Lona Abierta.

Smith, A. (1776). The wealth of nations. New York, NY: Random House.

Soledad Catoggio, M. (2010). The last Argentinean dictatorship (1976-1983): State terrorism engineering. France: Online Encyclopaedia of Mass Violence; Science Po University, Paris.

Svampa, M. (2012). Social movements, governments and new conflict scenarios in Latin America. Paraguay Magazine of Sociology, 139.

Talbot, C. (2006). Paradoxes and prospects of public value. Proceedings from the Tenth International Research Symposium on Public Management. Glasgow, United Kingdom.

The Federal Land Policy and Management Act of 1976. (1976). United States.

The Homestead Act of 1862. (1862). United States. 
The Land Ordinance of 1785. (1785). United States.

The Property Rights Alliance. (2015). United States.

Villanueva, L. F. (2002). The study of public policies. México: Miguel ÁngelPorrúa.

Vosburgh, M. (2002). Well-rooted? Land tenure and the challenges of globalization. Canada: McMaster University.

Weiss, C. H. (1977). Using social research in public policy making. Massachusetts: Heath \& Co.

Weiss, L. (1998). Globalization and the myth of the powerless state. Governing the economy in the global era. Cambridge, MA: Polity Press. 